Received: December 15, 2017

\title{
Study on the Application of Film and Television Education in Cultivation of College Students' Values*
}

\author{
Zhuowei Chen ${ }^{1}$ \\ Chengdu University of Technology
}

\begin{abstract}
College students are at the crossroads of life, and the cultivation of correct values has a great influence on their life. Film and television works have attracted the attention of college students, and their relaxing and interesting characteristics are also conducive to college students to get the education in leisure. Film and television education is to achieve educational goals through film and television works. This study summarizes the basic concepts of film and television education, film and television works and values, and summarizes the status quo of college students' values and the influence of mainland film and television works on college students' values through questionnaires. It is found that film and television works indeed play an important role in the cultivation of college students' values. Therefore, this study puts forward some suggestions such as setting up film and television appreciation course, enriching contents of film and television education, and breaking up the whole into parts so that film and television education can be carried out more efficiently and easily. This study can provide ideas for the ideological education of college students.
\end{abstract}

\section{Keywords}

College Students $\bullet$ Film and Television Education $\bullet$ Film and Television Works $\bullet$ Values

\footnotetext{
* Project Funded by SiChuan Network Culture Research Center(WLWH17-19).

${ }^{1}$ Correspondence to: Zhuowei Chen (MA), Chengdu University of Technology, College of Communication Science and Art,1\#, Dongsanlu, Erxianqiao, Chengdu 610059, China. Email: 522637702@qq.com
} 
College students are in the transition period of life that is an important stage of life growth. At this stage, the values of college students play a decisive role in the direction of their growth, and are of extraordinary significance to their entire life history. In addition, their values are of great significance not only to their own development, but also to the stability and development of the whole society, and even to the prosperity of the whole country and nation (Kubey, 2010).

Film and television works are popular, especially among college students, so they must shoulder the responsibility of spreading the right values. In college study and life, college students tend to accept moral education actively, but don't want to spend time focusing on ideological and political education. A relaxing way is more helpful for college students to receive subtle education (Buckingham, 2007). Thus, film and television works are very suited to this role. Therefore, colleges and universities must attach importance to the application of film and television works in the cultivation of college students' values.

\section{Film and Television Education and Values}

\section{Film and television education}

Film and television works refer to single or series of works which are recorded by professional equipment, performed by professional actors, dubbed by dubbing actors, and then presented to the audience by TELEVISION, screen, computer, or various mobile electronic devices (Sullivan \& Cunningham, 2007). Different from the single presentation form of words, sounds or images, film and television works combine a variety of elements with the most complete expression form and the most diverse presentation forms so that they are most popular with the audience (Buckingham, 2007).

Nowadays, the development momentum of film and television works is incomparable for the rich connotation, sufficient information, rich plots and direct emotional expression which are easy to cause the audience's resonance, and then cause more extensive attention. In the production process, the production of film and television works is a very complex and the entire production cycle often needs several processes. First, before the start of filming of film and television works, the script needs to be written and created. Second, when script is completed, the director can select actors according to the script, and make preparation and scheduling of the shooting work. Third, the filming of this work often lasts for several months. At last, when the filming of a work is completed, professional staff will be arranged for editing and post-production (Buckingham, 1998; Emerson \& Conroy, 2004).

To sum up, film and television works are produced by many kinds of professionals with wide influence and complicated production process, which needs to be paid attention to by researchers (Owens, 2000). Film and television works are generally characterized by three aspects. First, film and television works spread widely with a wide range of influence. There are many types of film and television works that take into account different types of audience. The threshold is relatively low and there are many presentation forms, making it convenient for the audience to watch anytime and anywhere. These two reasons make the film and television works have a large number of audience and great influence. Second, the timeliness of film and television works is obvious. 
Chen / Study on the Application of Film and Television Education in Cultivation of College Students' Values.

Most of the creative film and television works come from life. Their clothing, make-up and props are often affected by the trend of times, so film and television works often have obvious era imprint. Third, film and television works are comprehensive. Film and television works often contain a clear theme, rich connotation, twists and turns of plots, reflect a certain social phenomenon, and carry forward certain values. Therefore, film and television works are comprehensive works (Kubey, 1998; Strasburger \& Donnerstein, 2004).

Film and television education is a kind of education form making use of film and television works to achieve educational objectives. In film and television education, we must make full use of characteristics of film and television works to attract the attention of college students so that college students actively participate in film and television education.

\section{Values}

Values refer to the judgment of value. Different people have different values. The difference of values depends on differences in judgment and position on good and evil caused by differences in educational backgrounds and social attributes (Bonsack, 1958). Different interests determine different value orientation. Values determine people's behavior, which is closely related to a person's political attitude, moral cultivation, professional view and love view, and penetrates into all aspects of social life. Setting up correct values is the premise for college students become upright, active and enterprising to become pillars of society and shoulder the responsibility of revitalizing the motherland.

\section{Analysis of Influence of Film and Television Works on College Students' Values}

The influence of film and television education on college students' values mainly depends on the influence of film and television works on their values. This study analyzes the status quo of the development of Chinese film and television works, the status quo of college students' values, and the influence of film and television works on college students' values. The first one is obtained by analyzing and summarizing the existing data, and the latter two are obtained by questionnaires.

Questionnaires are mainly aimed at college students. A total of 1,000 questionnaires are issued, 965 are collected, and 964 are effective, accounting for $96.4 \%$. The questionnaires cover a number of majors with a male-female ratio of about $0.8: 1$, and a rural-urban ratio of about 1:1, and an average age of 21.5.

\section{Status quo of film and television works in China}

At present, the development status of film and television works in China mainly has the following characteristics:

The number of recorded TV shows has steadily increased while the number of access has declined As shown in Figure 1, in recent years, the number of recorded TV shows has steadily increased and the enthusiasm of TV shows producers is relatively high. Except for 2013-2014 and 2016-2017 when the number of TV shows 
decreased by a small margin, there was an increasing trend in the number from 2011 to 2017 with the growth rate up to about $13.5 \%$.

In sharp contrast to this trend, the number of TV shows allowed to be released has declined. Except for a brief upward trend in 2011-2012, there is a general downward trend from year to year. From 2012 to 2017, the rate of decline in the number of TV shows allowed to be released was as high as $37.9 \%$, indicating that the state attaches more importance to the supervision of television access.

The number of network TV shows has declined, but the amount of play has continued to rise with the development of video websites and the popularization of mobile devices, the broad masses of the people, especially the middle-aged and young people younger than 40 years old, are more and more inclined to use computers or mobile devices to watch film and television works. The network TV shows begins to flourish with the market share increasing remarkably.

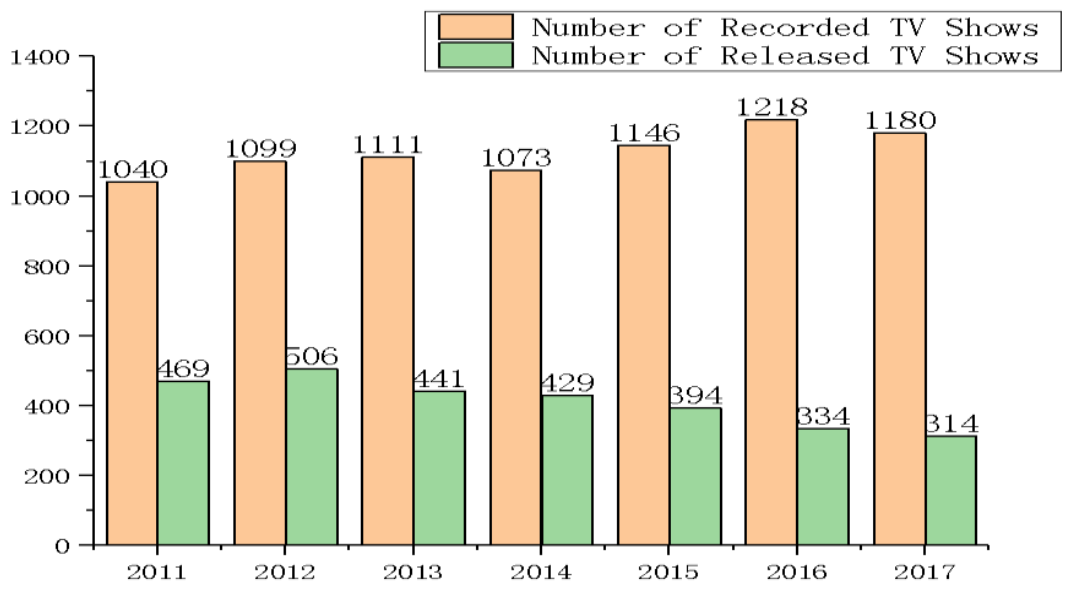

Figure 1. Number of recorded and released television series.

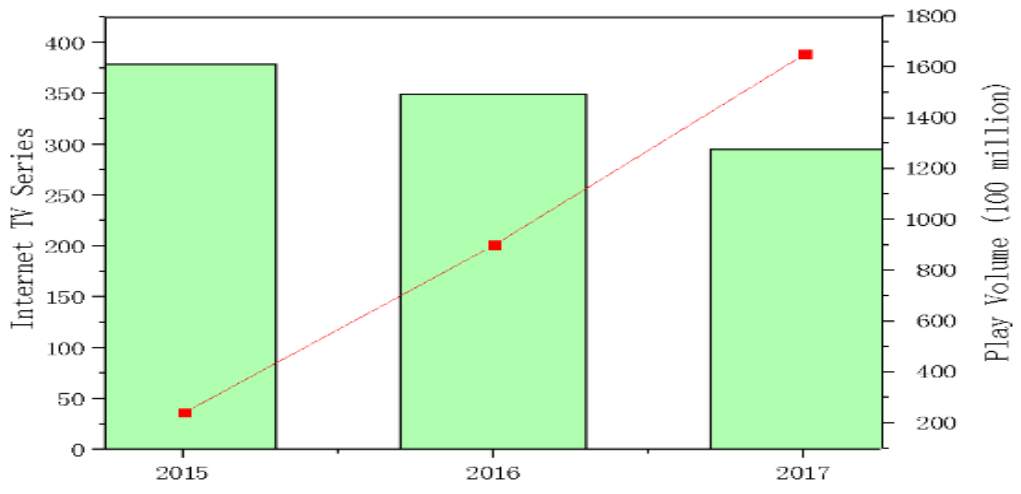

Figure 2. Number and amount of play of network TV shows. 
As shown in Figure 2, there were 369 network TV shows in 2015, but such scene seemed to be a flash in the pan. The number of network TV shows fell twice in the next two years. At the same time, the amount of play of network TV shows straight climbs. In these two trends, the increase in the number of hits for each network TV show is particularly obvious, proving that the market of network TV shows has great potential and it will become an important presentation form of film and television works.

High-score films are not attractive enough at the box office This study makes statistics on the scores of Chinese films in the top 30 of the box offices in 2016 and 2017. Among the 60 high-box-office films, there is no one with score of above 9, and only one with the score of 8-9. Most high-box-office films' score is below 7. This proves that the production level of Chinese films still needs to be improved, and the artistic value and theme connotation need to be enriched.

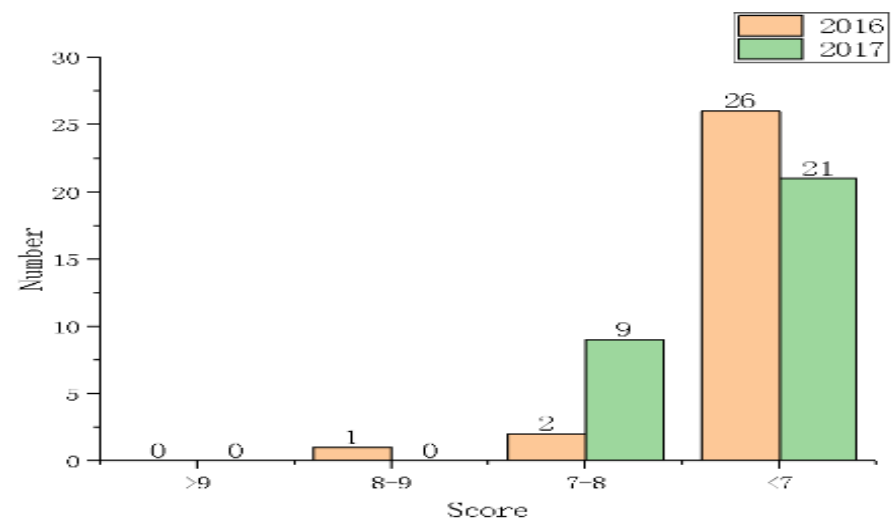

Figure 3. Douban score of Top 30 box office movies.

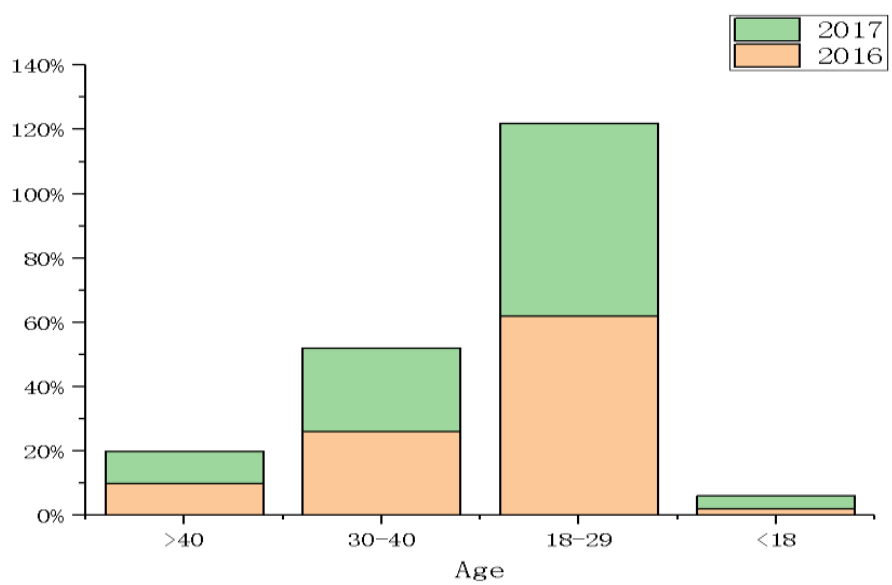

Figure 4. Age distribution of the audience. 
The audience is mainly the crowd of 18-40 years old: As shown in Figure 4, the minor and the middleaged over 40 years old seldom watch movies. The film audience is mainly in the age of 18 to 40 years, of which 18-29 years old young audience accounted for $62 \%$ and $60 \%$ of the total audience in 2016 and 2017 respectively. This part of the crowd is the main force of Chinese film audience.

To sum up, the supervision of film and television works in China is relatively strict, and the number of TV shows has declined in recent years. The development momentum of network TV shows is good. The film quality is not high enough and the young audience contributes to the box office of most films.

\section{Survey on status quo of college students' values}

The survey contents are divided into the following parts:

Politics For college students, it is helpful to cultivate their sense of mission and sense of responsibility to set up correct political values. As shown in Figure 5, a majority of college students support the leadership of the Party, support the Party's various principles and policies, a small number of college students hold a neutral attitude, and only a very few students express their opposition. This shows that the ideological and political education in colleges and universities is fruitful, and the college students hold a positive attitude towards the present political system, which contributes to the social stability and the long-term stability of the country.

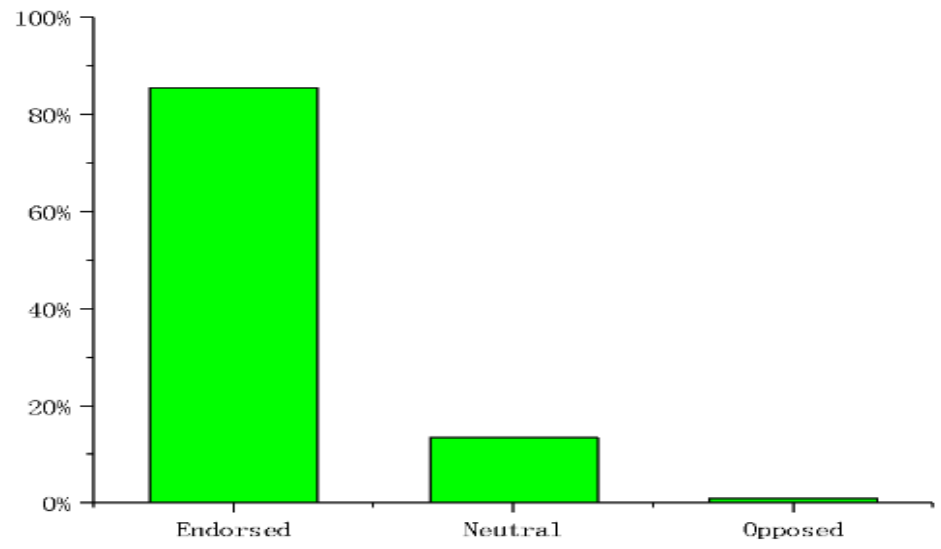

Figure 5. College students' attitude towards the current political system.

Morality As shown in Table 1, when college students face uncivilized, immoral and even illegal behaviors, such as making noise in public places, littering and stealing, most college students will choose to stop them. When faced with groups in need of help, around $80 \%$ of students choose to give a hand.

Career outlook Career outlook is not only related to the development of college students, but also closely related to the stability of the society. It is a common concern of the government, schools and parents, as well as 
Chen / Study on the Application of Film and Television Education in Cultivation of College Students' Values.

a major event related to national economy and people's livelihood. Setting up a correct career outlook can not only help college students to obtain employment smoothly, but also can maintain the stability of the society.

Table 1

College Students' Choice When Someone Needs to Stop or Need Help

\begin{tabular}{lccc}
\hline \multirow{2}{*}{ Behavior } & \multicolumn{3}{c}{ Attitude } \\
\cline { 2 - 4 } & Stop/help $(\%)$ & Not acting $(\%)$ & Not sure $(\%)$ \\
\hline Theft & 68.5 & 20.4 & 11.1 \\
Treading flowers and plants & 71.2 & 15.5 & 13.3 \\
Lettering in places of interest & 67.1 & 10.1 & 22.8 \\
Loud in public places & 74.2 & 15.9 & 9.9 \\
Littering waste & 70.3 & 14.8 & 14.9 \\
Someone on the bus needs to make a seat & 80.8 & 10.5 & 8.7 \\
Someone fell on the road & 84.1 & 11.5 & 4.4 \\
\hline
\end{tabular}

As shown in Figure 6, 83.7\% of college students think that they need to realize the value of life through their efforts, which shows that most college students have the right values. However, $7.1 \%$ and $6.9 \%$ of students believe that they can rely on their spouse or interpersonal relationship to realize their value of life. This shows that these two viewpoints are also widely spread among college students. In addition, $2.3 \%$ of the students have other different viewpoints or haven't considered the problem in depth.

83. $7 \%$

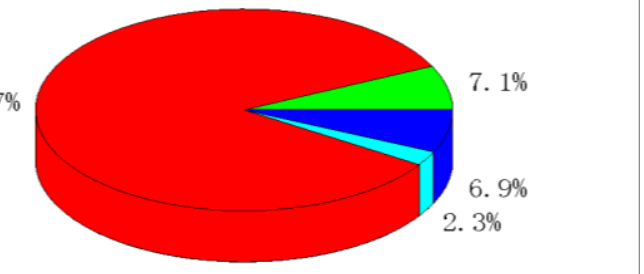

Figure 6. Ways for college students to realize their value in life.

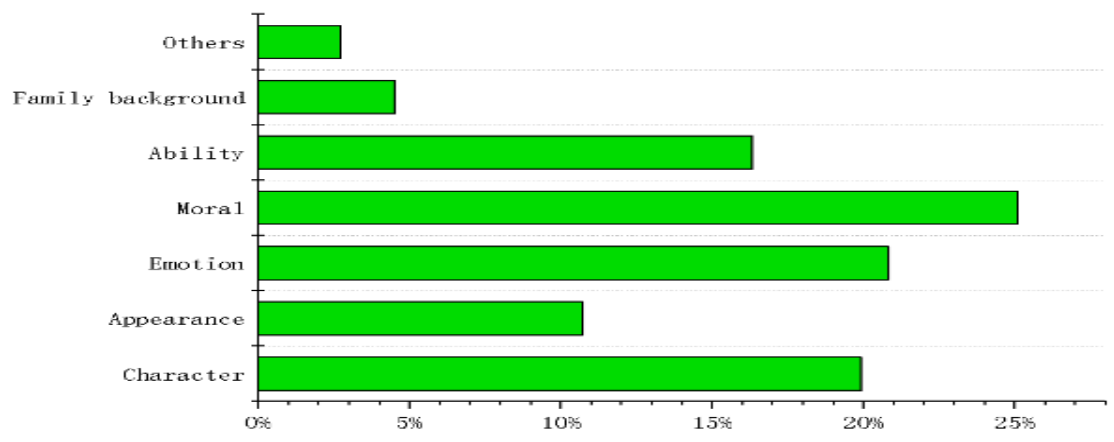

Figure 7. Ways for college students to realize their value in life. 
Love view Love view is also an important part of values. 53.7\% of the surveyed students already have love experience. As shown in Figure 7, through the survey on college students' love standards, it is found that the standards for love objects include morality and emotion and character between two parties, accounting for 19\%$26 \%$ respectively. Secondly, about $16.3 \%$ of students pay attention to the ability of love objects. Thirdly, about $10.7 \%$ of college students pay attention to the appearance of their love objects. In addition, there are a small number of students concerned about the family background and other factors of their love objects.

\section{Survey on the influence of film and television works on college students' values}

Table 2

College Students' Attitude Towards Film and Television Works

\begin{tabular}{lccc} 
& \multicolumn{3}{c}{ Attitude towards film and television works } \\
\cline { 2 - 4 } & Very interested & Interested & Not interested \\
\hline The proportion (\%) & 60 & 17 & 23 \\
Average time per day (h) & 2.8 & 1.0 & 0.5 \\
\hline
\end{tabular}

The general habits of college students to watch film and television works are shown in Table 2. More than half of the students are interested in watching film and television works and they will spend 2.8 hours a day in watching. $17 \%$ of the students are interested in film and television works, but they are not very indulgent and they just spend one hour a day in watching film and television works. In addition, $23 \%$ of the students are not interested in film and television works and just spend about half an hour a day in watching film and television works.

At present, there is no a uniform standard for the classification of film and television works. The more common classification method is to divide the film and television works into films, TV shows, documentaries, cartoons and other types according to the expression forms. Secondly, according to the contents, it can be divided into the main theme, emotion, martial arts, fantasy and science fiction. Thirdly, it is also possible to classify film and television works by region.

Table 3

Which One Shows More Correct Values

\begin{tabular}{|c|c|c|c|c|c|}
\hline & \multicolumn{5}{|c|}{ Content and proportion } \\
\hline Type & $\begin{array}{l}\text { TV series } \\
(30 \%)\end{array}$ & Movies (39\%) & $\begin{array}{c}\text { Documentaries } \\
(24 \%)\end{array}$ & Anime (3\%) & $\begin{array}{c}\text { Others } \\
(4 \%)\end{array}$ \\
\hline Theme & $\begin{array}{c}\text { Main theme } \\
(72 \%)\end{array}$ & Emotion (23\%) & Martial arts (2\%) & $\begin{array}{c}\text { Science fiction } \\
(2 \%)\end{array}$ & $\begin{array}{c}\text { Others } \\
(1 \%)\end{array}$ \\
\hline Area & $\begin{array}{l}\text { Mainland } \\
(85 \%)\end{array}$ & $\begin{array}{l}\text { Hong Kong and } \\
\text { Taiwan }(9 \%)\end{array}$ & $\begin{array}{c}\text { Europe and America } \\
(3 \%)\end{array}$ & $\begin{array}{c}\text { Japan and South } \\
\text { Korea }(1 \%)\end{array}$ & $\begin{array}{l}\text { Others } \\
(2 \%)\end{array}$ \\
\hline
\end{tabular}

The effect of film and television works on the dissemination of correct values is shown in Table 3 . In terms of type, the film works can spread the correct values (39\%), followed by the TV shows works (30\%) and documentaries (24\%). From the view of theme, most college students think that the main theme film and television works can most spread the correct values (72\%) and emotional film and television works can also spread the correct values (23\%) to a certain extent. From the point of view of region, the film and television works produced in mainland China are most recognized by college students $(85 \%)$ in the dissemination of correct values. 
Chen / Study on the Application of Film and Television Education in Cultivation of College Students' Values.

To sum up, most college students pay more attention to film and television works that indeed play an important role in the dissemination of correct values. In particular, the main theme film and television works produced by the mainland China have a particularly important role in cultivating the correct values of college students.

\section{Positive and negative effect of mainland film and television works on college students' values}

According to the survey data, the film and television works produced in mainland China have the greatest influence on college students' values, including both positive and negative effects. In the positive aspect, excellent film and television works can imperceptibly influence the thinking and decision-making of college students. For example, in recent years, the excellent patriotic films "Wolf Warriors I", "Wolf Warriors II", and "Operation Red Sea" which have been widely appreciated by the audience, have raised the climax of viewing and discussing in the whole country, and effectively promoted the patriotic education of college students. In the negative aspect, some film and television works don't play a good guiding role but play a negative guiding role for the uneven quality of film and television works in the market. For example, there are some violent and bloody scenes in some film and television works, and some idol plays are full of money worship and hedonism, all of which can cause bad effects on college students.

\section{Strategy of Cultivating College Students' Values through Film and Television Education}

It is found from the survey that some college students don't have their own choice tendency when choosing film and television works, but are easily influenced by the network and the surrounding opinion environment. Some college students only pay attention to the cast when choosing film and television works and some choose works just out from curiosity. In the face of this misunderstanding, it is necessary to set up the correct choice of film and television works for college students so that the film and television works containing incorrect values can be automatically filtered out. Firstly, colleges and universities can guide college students to discuss the connotation of the values of film and television works through film and television education, and often sound the alarm bell to the consequence that college students are affected by the bad values so that they can improve their vigilance and resist the erosion of bad values consciously. Colleges and universities can also set up film and television contrast appreciation courses to teach college students so that they can clearly understand the difference between excellent works and bad works.

Secondly, colleges and universities should also enrich the contents of film and television education. As mentioned above, the development of network TV shows is rising perpendicularly. The Chinese main theme films, TV shows and even documentaries are spreading the correct value orientation. In the past, the film and television education is usually dominated by films, which is too simple. Documentaries and TV shows including network TV shows should also be introduced into film and television education. 
Thirdly, the characteristics of film and television works determine that film and television education can't be confined in the classroom. Its interest decides that the pressure that the film and television education brings to students is small. Therefore, the whole can be broken up into parts so that the film and television education can be well combined together with student's leisure and entertainment.

\section{Conclusion}

(1) The supervision of film and television works in China is relatively strict, and the number of TV shows has declined in recent years. The young audience contributes to the box office of most films and pays more attention to film and television works. The development momentum of network TV shows is good, which should be included in film and television education.

(2) Most college students have right values, but there are also some students who need to strengthen their guidance.

(3) Most college students pay close attention to film and television works and acknowledge that film and television works are of great significance in the dissemination of correct values. When discussing the theme and production region of works, students believe that the main theme film and television works produced by mainland China play an important role in cultivating correct values

(4) In the process of film and television education, we need to further expand the contents of curriculum, enrich the forms of curriculum, and strengthen the guidance so as to expand the film and television education to extracurricular leisure and entertainment.

\section{References}

Buckingham, D. (2007). Digital media literacies: Rethinking media education in the age of the internet. Research in Comparative \& International Education, 2(2), 43-55. http://dx.doi. org/10.2304/rcie.2007.2.1.43

Buckingham, D. (2007). Media education and the end of the critical consumer. Higher Education, 73(3), 309327. http://dx.doi. org/10.17763/haer.73.3.c149w3g81t381p67

Buckingham, D. (1998). Media education in the uk: moving beyond protectionism. Journal of Communication, 48(1), 11. http://dx.doi. org/10.1111/j.1460-2466.1998.tb02735.x

Bonsack, W. K. (1958). Human values. Science, 127(3313), 1513-1514. http://dx.doi. org/10.1126/science.127.3313.1513

Emerson, T. L. N., \& Conroy, S. J. (2004). Have ethical attitudes changed? An intertemporal comparison of the ethical perceptions of college students in 1985 and 2001. Journal of Business Ethics, 50(2), 167-176. http://dx.doi. org/10.1023/B:BUSI.0000022126.48574.6e 
Chen / Study on the Application of Film and Television Education in Cultivation of College Students' Values.

Kubey, R. (2010). Obstacles to the development of media education in the united states. Journal of Communication, 48(1), 58-69. http://dx.doi. org/10.1111/j.1460-2466.1998.tb02737.x

Kubey, R. (1998). Obstacles to the development of media education in the united states. Journal of Communication, 48(1), 12. http://dx.doi. org/10.1111/j.1460-2466.1998.tb02737.x

Owens, T. J. (2000). Self, identity, and social movements. Contemporary Sociology, 30(6), 588. http://dx.doi. org $/ 10.2307 / 3089001$

Sullivan, E., \& Cunningham, B. (2007). Educating principled citizens: a small private college advances its longstanding mission via lessons learned from a new values initiative at a large public university. Journal of College \& Character, 8(1), 1-9. http://dx.doi. org/10.2202/1940-1639.1147

Strasburger, V. C., \& Donnerstein, E. (2004). Children, adolescents, and the media: issues and solutions. Current Problems in Pediatric \& Adolescent Health Care, 34(2), 54-113. http://dx.doi. org/10.1016/j.cppeds.2003.08.001 